\title{
Monitoring the Antibacterial Effect of Rosin Acids in an Austrian Beet Sugar Plant by Amplicon-Based Sequencing and Flow Cytometry
}

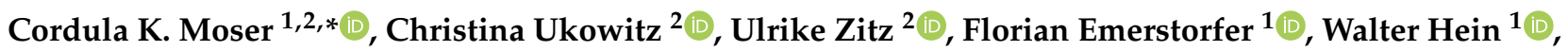 \\ Wolfgang Kneifel ${ }^{2} \mathbb{D}$ and Konrad J. Domig ${ }^{2} \mathbb{D}$ \\ 1 AGRANA Research \& Innovation Center GmbH, Department of Sugar Technology, Josef-Reither-Straße 21-23, \\ A-3430 Tulln, Austria; florian.emerstorfer@agrana.com (F.E.); walter.hein@agrana.com (W.H.) \\ 2 Department of Food Science and Technology, Institute of Food Science, BOKU-University of Natural \\ Resources and Life Sciences Vienna, Muthgasse 18, A-1190 Vienna, Austria; \\ christina.ukowitz@hotmail.com (C.U.); ulrike.zitz@boku.ac.at (U.Z.); wolfgang.kneifel@boku.ac.at (W.K.); \\ konrad.domig@boku.ac.at (K.J.D.) \\ * Correspondence: cordula.moser@agrana.com
}

check for updates

Citation: Moser, C.K.; Ukowitz, C.; Zitz, U.; Emerstorfer, F.; Hein, W.;

Kneifel, W.; Domig, K.J. Monitoring the Antibacterial Effect of Rosin Acids in an Austrian Beet Sugar Plant by Amplicon-Based Sequencing and Flow Cytometry. Appl. Sci. 2021, 11, 737. https://doi.org/10.3390/ app11020737

Received: 11 December 2020 Accepted: 11 January 2021 Published: 14 January 2021

Publisher's Note: MDPI stays neutral with regard to jurisdictional clai$\mathrm{ms}$ in published maps and institutional affiliations.

Copyright: (C) 2021 by the authors. Licensee MDPI, Basel, Switzerland. This article is an open access article distributed under the terms and conditions of the Creative Commons Attribution (CC BY) license (https:// creativecommons.org/licenses/by/ $4.0 /)$.

\begin{abstract}
For decades, microorganisms in beet sugar production have been studied using culturebased methods. However, these methods are not sufficient to describe such a complex bacterial community. In this study, therefore, an amplicon-based sequencing technique (Illumina MiSeq platform) was applied to characterize the bacterial community and its dynamics in the extraction area and juice purification station of an Austrian beet sugar plant. Depending on the process conditions thermophilic bacteria, such as Geobacillus spp., Caenibacillus spp., and Thermus spp., and mesophilic bacteria, such as Leuconostoc spp. and Bacillus spp., were found. Besides these microbiological characteristics, the antimicrobial effect of a rosin acid-based product (Defostab 220) on the bacterial communities was investigated in industrial and laboratory trials. The antimicrobial effect of a given concentration of rosin acid varies from bacteriostatic to bactericidal effects on different occurring groups of bacteria.
\end{abstract}

Keywords: beet sugar factory; bacterial communities; antimicrobial; rosin acids; flow cytometer

\section{Introduction}

The extraction of sucrose from sugar beets takes place in several steps. In Austrian plants, a combination of a countercurrent mixer and an extraction tower is employed. First, sugar beets are sliced into cossettes, which are treated in a solid-liquid extraction process using the countercurrent principle to extract sucrose (Figure 1).

In this area of the tower extraction system, the temperatures vary from $20{ }^{\circ} \mathrm{C}$ in raw juice to $72{ }^{\circ} \mathrm{C}$ in the tower end of the countercurrent mixer. In the next step, juice purification, temperatures of over $90{ }^{\circ} \mathrm{C}$ and $\mathrm{pH}$ values of up to 12 are necessary to reduce non-sugars and to stabilize the juice. Then, water from the so-called thin juice is evaporated, and the resulting thick juice is used to crystallize white sugar in a multistage crystallization process [1]. Due to the conditions of high $\mathrm{pH}$ values and high temperatures in these processing steps, the growth of microorganisms was not considered to be of any technological relevance for a long time. This assumption changed in 1930 with the observation of microorganisms influencing the storage of beets [2]. In addition to technological challenges, microorganisms can cause financial losses due to sucrose losses, as sucrose may be metabolized into different microbiological metabolites. The total sucrose losses caused by microorganisms are calculated to range between $0.02 \%$ and $0.66 \%$ of processed beets [3,4]. Since 1930, various methods have been employed to determine the microbiota present during sugar beet production to obtain a better understanding of the process and to limit microbial activity. For example, a large set of different antimicrobial 
agents have been applied to combat microorganisms in different processing steps. Most investigations have been carried out using culture-based methods [5-8]. These methods are limited because many species are difficult to culture or are even not culturable due to special growth requirements. Furthermore, culture-based methods require preselection of media and cultivation conditions [9]; this preselection of incubation conditions may subsequently influence the identification of microorganisms, which is undesired. Characterizing the whole bacterial community and its diversity is therefore quite difficult. This difficulty led to the use of molecular-based methods mostly based on DNA analysis that are more sensitive, more accurate and more specific and may even be faster [10]. Despite this progress, microscopic or cultural methods are most often used to identify microorganisms. Some methods, which have also been applied in the sugar industry, combine culture-based methods with molecular biological methods, such as $16 \mathrm{~S}$ rDNA sequencing or Matrix Assisted Laser Desorption Ionization-Time of Flight Mass Spectrometry (MALDI-TOF MS), to identify isolates [11-13]. The advantages of these combined molecular biological methods include identifying microorganisms with greater sensitivity and accuracy. However, these methods still have the disadvantage of requiring pure cultures. Further applicable culture-independent methods could include real-time polymerase chain reaction (PCR) or specific microscopic techniques such as transmission electron microscopy (TEM) or scanning electron microscopy (SEM) [10]. Detecting and characterizing all occurring microorganisms in one sample is very challenging and almost impossible with the methods mentioned above, as the interactions between microorganisms may interfere with the detectability of the microbiota.

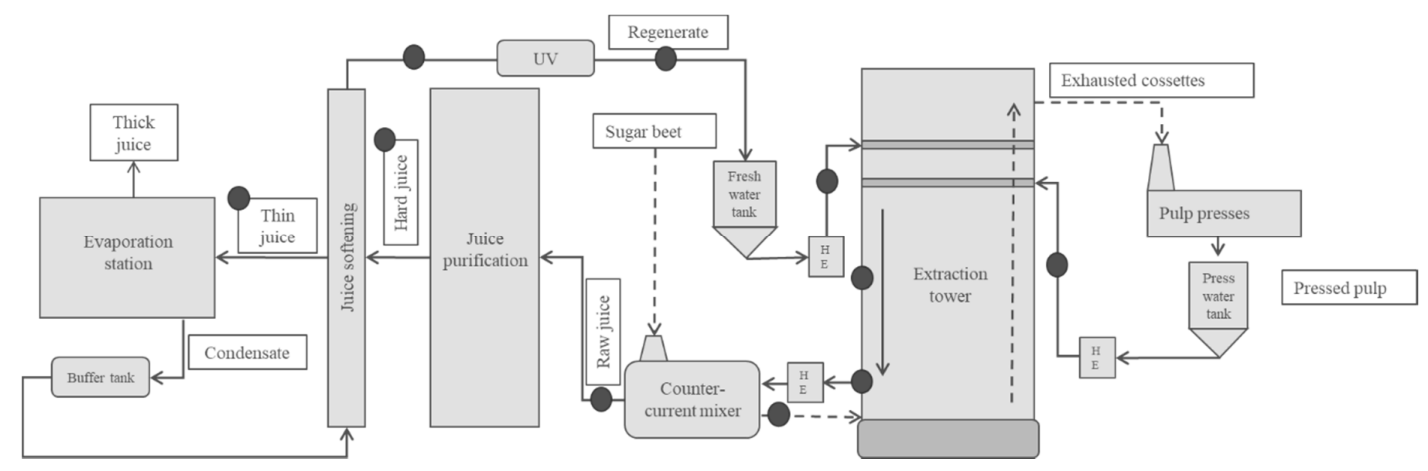

Figure 1. Processing scheme of beet sugar production in the investigated factory with detailed description of counter-current principle in the extraction area. The dashed line shows the flow of the beet cossettes and the continuous line represents the liquid flow. The sampling points are marked with grey dots. HE: heat exchange.

A possible time and cost saving solution for characterizing a complex bacterial community is utilizing high-throughput sequencing techniques. These techniques provide qualitative and semi-quantitative data about the composition of the bacterial community. Flow cytometric analyses can help to normalize these data and additionally provide information about the physiological state of the microorganisms. Notably, this application of flow cytometric analysis is becoming increasingly important for rapid, ecological, environmental, and food microbiology studies [14-16].

\section{Materials and Methods}

To date, no investigations have been conducted to determine the bacterial community, including non-culturable organisms in beet sugar production and to characterize the influence of microbial interactions. Due to the processing conditions, such as lower temperatures and $\mathrm{pH}$ values, microorganisms are found mostly in the beet end of production, extending from the fresh beet to the evaporation station $[2,8,12]$. Therefore, the present work attempts to characterize the microorganisms present in the extraction area and juice purification station in an Austrian beet sugar factory by amplicon-based sequencing for a more detailed description of the microbial composition in addition to the investigations 
carried out by Kohout et al. [13]. Additionally, the quantities and physiological state of microorganisms were monitored by flow cytometry. To the best of our knowledge, this report describes for the first time the application of two high-throughput methods for the characterization of microorganisms in the sugar industry, including a more detailed evaluation of the antibacterial effects of a rosin acid-based formulation (Defostab 220) in a lab and industrial scale in parallel $[13,17,18]$. Since 2000, AGRANA has been using rosin acid product containing abietic acid, combined with fatty acids to combat microorganisms in the sugar industry. Like the hop acids, these show a stabilizing effect on the $\mathrm{pH}$ value [18]. In addition, building on the knowledge from Kohout et al. [13], this study aims to investigate how the resin acids affect the bacteria by analyzing them with flow cytometer technique.

\subsection{Trial Setup}

In total, 156 samples were obtained from an Austrian beet sugar plant with a daily beet slicing capacity of approximately 12,000 $\mathrm{t}$ within three months (November, December, and January) during the $2017 / 18$ season. Additionally, to the samples from the extraction area microbiologically analysed by Kohout et al. [13], also 48 samples from juice purification (Figure 1; thin juice, hard juice, eluate before and after UV-treatment) were taken for more detailed analyses including amplicon-based sequencing to obtain further knowledge about the bacterial community. The sampled extraction system had two extraction lines, two extraction towers and two countercurrent mixers. The press water and fresh water used for the two extraction lines were identical for both lines. The raw juice produced in both lines was combined, and a sample was taken from the combined juice. The trial was set up according to Kohout et al. [13]. In November 2018, December 2018, and January 2019, samples were taken on two consecutive days when the rosin acid-based antimicrobial formulation was applied in the extraction area and on two consecutive days when no antimicrobial agent was used in the whole extraction process. Sampling using sterile sampling containers at all sites of extraction (Nine sampling points: raw juice, juice tower 1 and 2, juice of mid-tower 1 and 2, cossette-juice mixture 1 and 2, fresh water and press water) and all sites in juice purification (Four sampling points: hard juice, thin juice, eluate before and after UV-treatment) took place at the same time in the afternoon on day 1 and 2 .

\subsection{DNA Isolation}

All samples were treated immediately after sampling: $50 \mathrm{~mL}$ of every sample from the extraction process, with the exception of fresh water, was aseptically transferred into $50 \mathrm{~mL}$ sterile centrifugation tubes (VWR, Radnor, PA, USA), and afterwards, they were centrifuged at $8000 \mathrm{rpm}$ for $6 \mathrm{~min}$ at $4^{\circ} \mathrm{C}$. The supernatant was discarded such that the remaining pellet was still covered with liquid. Because of the very low DNA concentration expected in samples from the juice purification process and fresh water, $500 \mathrm{~mL}$ samples were centrifuged under the same conditions as mentioned above to generate pellets for DNA extraction. The pellets were stored at $-20^{\circ} \mathrm{C}$ until further processing. Total bacterial DNA was extracted using the DNeasy PowerFood Microbial Kit (Qiagen, Venlo, Netherlands) according to the manufacturer's instructions. To quantify DNA concentrations, a Qubit 2.0 fluorometer with the dsDNA HS Assay Kit (Invitrogen, Waltham, MA, USA) was applied.

\subsection{Amplicon-Based Metagenomic Sequencing (Illumina MiSeq) and Metagenomic Data Processing}

The V3 and V4 regions of the bacterial 16S rRNA gene were sequenced by creating two-step and three-step, Nextera barcoded, PCR libraries using the locus specific primer pair 341F (5'-CCT ACG GGN GGC WGC AG-3') and 805R (5'-GAC TAC HVG GGT ATC TAA TCC $\left.-3^{\prime}\right)$. The PCR libraries were sequenced on an Illumina MiSeq platform using a v3 600 Cycle kit (Illumine Inc., San Diego, CA, USA) to produce paired-end reads. The reads that passed Illuminas chastity filter were subject to demultiplexing and trimming of any Illumina adaptor residuals by Illuminas own real-time analysis software (MiSeq reporter software v2.6 (Illumina Inc., San Diego, CA, USA); no further refinement or selection). The FastQC software version 0.11.7 (Babraham Institute, Cambridge, UK) was 
used for determining the quality of the reads [19]. Paired-end reads were discarded if the locus-specific V3-V4 primer could not be trimmed from the sequencing reads with the software cutadapt v1.18 [20]. The sequenced molecule was reformed in silico with the software USEARCH version 11.0.667 by merging the trimmed forward and reverse reads of each paired-end read with a minimal overlap of $15 \mathrm{bp}$ [21]. After a quality filtration step of the merged sequences, whereby maximal one expected erroneous base per merged read was accepted other reads including ambiguous bases or outliers regarding the expected amplicon size distribution were discarded. The surviving reads were denoised using the UNOISE algorithm implemented in USEARCH to form operational taxonomic units (OTUs) with a similarity level of $97 \%$ discarding singletons and chimeras in the process [22]. After filtering the resulting OTU abundance table for possible barcode bleed-in contaminations with the UNCROSS algorithm, the UNBIAS algorithm was used for adjusting the abundances for $16 \mathrm{~S}$ copy numbers $[23,24]$. OTUs were compared against the reference sequences of the RDP $16 \mathrm{~S}$ database release 11. The determination of the taxonomies was done with the SINTAX algorithm implemented in USEARCH whereby a minimum confidence threshold of 0.6 was set $[25,26]$. For visualizing the metagenome krona charts were used [27]. Alpha diversity was calculated by using the richness (observed), Simpson and Shannon indices. The weighted UniFrac distance method based on rarefied OTU abundance counts per sample was used for the calculation of the beta diversity. To expose possible patterns of inter-sample relations, these sample distances were then used in a detrended correspondence analysis (DCA). Further analyses of the tested groups such as the variance (PERMANOVA) and similarities (ANOSIM) were done. Alpha diversity calculations (Simpson and Shannon indices) beta diversity calculations including DCA and rarefaction analysis were performed with the $\mathrm{R}$ software packages phyloseq $\mathrm{v} 1.22 .3$ and vegan v2.5-1. The Simpson index can take values between 0 and 1.0; the closer the value is to 1.0, the less diverse the microbial community is. This index is contrary to the Shannon index, where a high value means a high diversity of the microbial population [28-30]. The library construction, sequencing and data analysis described in this section were performed by Microsynth AG (Balgach, Switzerland).

\subsection{Live/Dead Quantification of Bacteria by Flow Cytometry}

Twenty-millilitre aliquots of the samples were frozen at $-20^{\circ} \mathrm{C}$. SYBR-Green (Invitrogen, Thermo Fisher Scientific, Waltham, MA, USA) working solution at a concentration of 1:100 (10,000* concentrate in dimethyl sulfoxide (Merck KGaA, Darmstadt, Germany)) [31] and propidium iodide (PI, Invitrogen, Thermo Fisher Scientific, Waltham, MA, USA) in ultrapure water at a concentration of $0.5 \mathrm{mg} / \mathrm{mL}$ were used for the staining procedure to determine the physiological state of the cell [15].

Samples taken from the extraction area (except for fresh water) were passed through $20 \mu \mathrm{m}$ filters (Sysmex Austria GmbH, Wien, Austria) and diluted 1:10 with 0.9\% sodium chloride solution (Merck KGaA, Darmstadt, Germany). Raw juice and samples from the mini-fermenter trial were diluted 1:100 before staining. For samples from juice purification, no filtration step was necessary to remove fine particles. SYBR Green was added at a final dilution of 1:10,000, and incubation was performed at $37^{\circ} \mathrm{C}$ for $15 \mathrm{~min}$ in the dark. After adding PI at a final concentration of $5 \mu \mathrm{g} / \mathrm{mL}$ [31], the prepared samples were measured with CyFlow Cube 6 (Sysmex Austria GmbH, Wien, Austria). Fluorescence from SYBR Green-stained cells was acquired on the FL1 channel $(525 \mathrm{~nm})$, and the signal from PIstained cells was acquired on the FL3 channel $(700 \mathrm{~nm})$. The forward scattered light is called forward scatter and correlates with the size of the cell. Wider scattered light is called side scatter and describes the structure of the cell [15]. The flow rate was set to $1 \mu \mathrm{L} / \mathrm{s}$, approximately 4000-5000 events/s, and the measurement duration was set to $50 \mathrm{~s}$. Before each measurement, the instrument was washed for $50 \mathrm{~s}$ with sheath fluid. FCS Express Cytometry Software v6 (De Novo Software, Pasadena, CA, USA) was used for data analysis. Gates to quantify live and dead populations were established with the help of controls with living or dead cells in the sample matrix. Therefore, samples with different matrices 
were centrifuged (13,400 rpm, $10 \mathrm{~min})$ before sterile filtration, and they were diluted. The E. coli DSM 5695 suspension (diluted in $0.9 \%$ sodium chloride solution) for defining the dead cell gate was heated in the microwave $\left(>100{ }^{\circ} \mathrm{C} ; 10 \mathrm{~min}\right)$ to kill the bacteria. The effect was verified by attempting to culture the samples. To set the viable cell gate, an E. coli DSM 5695 suspension (diluted in $0.9 \%$ sodium chloride solution) was added to the sterile-filtered sample and to the filtered sample to separate the signal of living cells from the autofluorescence background signal.

\subsection{Mini-Fermenter Trial Setup}

Samples from the juice of the central part of the extraction tower (mid-tower) were taken in December 2018 and stored in $20 \mathrm{~mL}$ aliquots at $-20{ }^{\circ} \mathrm{C}$. The aliquot was added to $480 \mathrm{~mL}$ of a nutrient broth $(10 \mathrm{~g} / \mathrm{L}$ Bacto peptone, $5 \mathrm{~g} / \mathrm{L}$ meat extract, $5 \mathrm{~g} / \mathrm{L}$ yeast extract, $1.31 \mathrm{~g} / \mathrm{L} \mathrm{K}_{2} \mathrm{HPO}_{4} \cdot 3 \mathrm{H}_{2} \mathrm{O}, 0.1 \mathrm{~g} / \mathrm{L} \mathrm{MgSO}_{4} \cdot 7 \mathrm{H}_{2} \mathrm{O}$ and $\left.0.01 \mathrm{~g} / \mathrm{L} \mathrm{FeSO} \cdot 7 \mathrm{H}_{2} \mathrm{O}\right)$ preheated in a mini-fermenter to $65{ }^{\circ} \mathrm{C}$ [18]. The temperature and $\mathrm{pH}$ value (Mettler-Toledo $\mathrm{GmbH}$, Vienna, Austria) were measured online every $5 \mathrm{~s}$ with a customized program written in C\#. L-Lactic acid and glucose were analysed every hour with Super GL (Dr Müller Gerätebau $\mathrm{GmbH}$, Freital, Germany) following the manufacturer's guidelines [32] until a pH value of 5.8 was reached. At a $\mathrm{pH}$ value of approximately 5.8, antibacterial agent was dosed to stop lactic acid formation and stabilize the $\mathrm{pH}$ value. The necessary concentration of the antibacterial agent was determined in pretrials. One millilitre of rosin acid-based product, Defostab 220 (Defotec Entschäumer Vertriebs-GmbH, Krefeld, Germany) was added at a concentration of $3 \mathrm{mg} / \mathrm{L}$. For the control sample, the trials were carried out the same way without adding the product. Before dosing, 15, 30, and $45 \mathrm{~min}$ after dosing and at the end of the trial (after $24 \mathrm{~h}$ ), samples were collected for viability measurement and additional L-lactic acid and glucose analyses. The mean value and standard deviation of all analyses were calculated from at least three mini-fermenter tests and compared with the values obtained from untreated mini-fermenters (control samples).

\subsection{Statistical Analyses}

All data were investigated by repeated measures analysis (MANOVA) using JMPC pro software (JMPC pro 15-1-0, 6-bit version, 2019 SAS Institute, Inc., Cary, NC, USA). Statistical analysis of the industrial trial results was performed as described by Kohout et al. (JMP Pro Model specification: MANOVA fit with repeated measures response) [13]. Again, "sampling points", "treatments" and "periods", as well as their simple interaction terms, were treated as fixed model effects, and effects on the response variables were considered to be significant at $p<0.05$. Additionally, the same model was applied with special focus on the extraction area. Therefore, a reduced data set was analysed by including only responses from samples taken at the extraction tower and the countercurrent mixer. Data from the mini-fermenter trial were also analysed by repeated measures analysis but only with "treatments" as a fixed model effect to detect significance between differing treatments as well as time effects during sampling. Furthermore, multiple comparisons for responses by condition based on Least Significant Difference (LSD) means were made to demonstrate the effects of dosing rosin acid-based product between sampling during the mini-fermenter trial.

At the beginning, the plausibility and validity of the raw data were verified, and the bacterial count results were subjected to log10 transformation. The repeated measures analysis was performed separately for each response variable to obtain a standard univariate fit. Significant effects were further examined by contrast analysis with Bonferroni correction at a significance level of $5 \%$.

\section{Results and Discussion}

\subsection{Identification of Microorganisms in the Extraction Area and Juice Purification}

The output of the metagenomic sequencing of the duplicates sampled on two consecutive days in an Austrian sugar factory over the beet sugar process was in total approx. 
22.1 million reads with a length of $300 \mathrm{bp}$. The reads and operational taxonomic units (OTU) per sample are tabularized in Table 1 . The majority of total bacteria sequences over all samples were from the phyla Thermus (60\%), followed by Firmicutes (29\%) and Proteobacteria (6\%). The Firmicutes contained mostly the class Bacilli (99\%), which are divided in Bacillales (79\%) and Lactobacillales (21\%).

Table 1. Reads and Operational taxonomic unit (OTU) calculated based on amplicon-based metagenomic (Illumina MiSeq) sequencing analyses and bacterial count based on flow cytometry measurements. Values are expressed as means of two replicates and the standard deviations (SD).

\begin{tabular}{|c|c|c|c|c|c|c|c|c|c|c|}
\hline \multirow{3}{*}{ Periods } & \multirow{3}{*}{$\begin{array}{l}\text { Process } \\
\text { Stage }\end{array}$} & \multirow{3}{*}{ Sampling Points } & \multicolumn{4}{|c|}{ Reads } & \multicolumn{4}{|c|}{ OTU } \\
\hline & & & \multicolumn{2}{|c|}{ Rosin Acid } & \multicolumn{2}{|c|}{ No Treatment } & \multicolumn{2}{|c|}{ Rosin Acid } & \multicolumn{2}{|c|}{ No Treatment } \\
\hline & & & Mean & SD & Mean & SD & Mean & SD & Mean & SD \\
\hline \multirow{13}{*}{ November } & \multirow{9}{*}{ Extraction } & Fresh water & $12,228.00$ & * & 15,911 & * & 4 & * & 9 & * \\
\hline & & Press water & $15,090.50$ & $10,115.16$ & 3251.5 & 2305.88 & 16 & 1.41 & 11 & 1.41 \\
\hline & & Juice of mid-tower 1 & $26,274.50$ & 2267.69 & 19,095 & $24,744.49$ & 13 & 0.00 & 3.5 & 2.12 \\
\hline & & Juice of mid-tower 2 & $15,928.00$ & $21,374.42$ & $24,194.5$ & 6767.72 & 12.5 & 0.71 & 2.5 & 0.71 \\
\hline & & Tower juice 1 & $18,143.50$ & 2551.95 & 12,786 & * & 13 & 1.41 & 12 & * \\
\hline & & Tower juice 2 & $26,064.50$ & 8954.09 & $12,136.5$ & 692.26 & 19 & 1.41 & 9.5 & 4.95 \\
\hline & & Cossette-juice mixture 1 & $15,843.00$ & 3358.76 & 5182 & 6313.05 & 13.5 & 3.54 & 9 & 1.41 \\
\hline & & Cossette-juice mixture 2 & $30,421.00$ & $12,539.83$ & 6596 & 9277.24 & 32 & 12.73 & 10 & 9.90 \\
\hline & & Raw juice & 3726.00 & 3445.02 & $10,562.5$ & 8495.89 & 55 & 8.49 & 25 & 24.04 \\
\hline & \multirow{4}{*}{$\begin{array}{c}\text { Juice } \\
\text { purification }\end{array}$} & Hard juice & $178,524.00$ & $28,550.14$ & 17,3944 & $15,253.71$ & 1 & 0.00 & 21 & 4.24 \\
\hline & & Thin juice & $119,452.00$ & $22,429.43$ & 124,578 & 6853.28 & 1.5 & 0.71 & 1 & 0.00 \\
\hline & & Eluat before UV & $18,015.00$ & $*$ & $15,325.5$ & 4868.43 & 4 & $*$ & 4 & 0.00 \\
\hline & & Eluat after UV & $14,614.50$ & 211.42 & $22,596.5$ & $11,916.87$ & 4 & 0.00 & 4 & 0.00 \\
\hline \multirow{13}{*}{ December } & \multirow{9}{*}{ Extraction } & Fresh water & $43,396.50$ & $35,391.40$ & $12,021.5$ & 3995.86 & 3.5 & 0.71 & 4 & 0.00 \\
\hline & & Press water & 9637.00 & 562.86 & 8569 & 1043.69 & 19.5 & 2.12 & 16.5 & 0.71 \\
\hline & & Juice of mid-tower 1 & $26,288.50$ & 3160.06 & 27,570 & 6057.08 & 14 & 5.66 & 7.5 & 4.95 \\
\hline & & Juice of mid-tower 2 & $30,174.00$ & $*$ & $38,261.5$ & 3270.37 & 13 & $*$ & 2 & 0.00 \\
\hline & & Tower juice 1 & $13,319.00$ & 3798.58 & $11,126.5$ & 1731.70 & 31.5 & 24.75 & 11 & 0.00 \\
\hline & & Tower juice 2 & $15,014.50$ & 7008.14 & 12,591 & 76.37 & 63.5 & 24.75 & 11 & 0.00 \\
\hline & & Cossette-juice mixture 1 & 8181.00 & $10,504.78$ & $11,426.5$ & 1997.58 & 64.5 & 40.31 & 15.5 & 4.95 \\
\hline & & Cossette-juice mixture 2 & $22,260.50$ & $10,693.58$ & 12,601 & 353.55 & 71 & 32.53 & 11 & 0.00 \\
\hline & & Raw juice & $22,420.50$ & 5838.58 & 7326.5 & 2069.70 & 119.5 & 4.95 & 70 & 12.73 \\
\hline & \multirow{4}{*}{$\begin{array}{c}\text { Juice } \\
\text { purification }\end{array}$} & Hard juice & $143,327.00$ & $10,534.48$ & $123,280.5$ & $84,686.64$ & 18 & 14.14 & 19.5 & 4.95 \\
\hline & & Thin juice & $145,599.00$ & 2979.75 & 126,441 & 4167.69 & 1 & 0.00 & 1 & 0.00 \\
\hline & & Eluat before UV & $70,983.50$ & $86,489.77$ & $208,905.5$ & $100,409.87$ & 6 & 2.83 & 8.5 & 2.12 \\
\hline & & Eluat after UV & $104,739.00$ & $*$ & 42,854 & $28,629.34$ & 6 & * & 7 & 2.83 \\
\hline \multirow{13}{*}{ January } & \multirow{9}{*}{ Extraction } & Fresh water & $10,228.00$ & * & 43,980 & $34,129.22$ & 4 & * & 21 & 24.04 \\
\hline & & Press water & $11,162.50$ & 3650.79 & 9279.5 & 1177.33 & 18.5 & 2.12 & 14 & 0.00 \\
\hline & & Juice of mid-tower 1 & $18,860.50$ & $10,550.74$ & $36,115.5$ & 1593.11 & 11.5 & 3.54 & 12.5 & 3.54 \\
\hline & & Juice of mid-tower 2 & 1852.50 & 1697.76 & 32,030 & 4236.98 & 29.5 & 6.36 & 9 & 4.24 \\
\hline & & Tower juice 1 & $15,531.50$ & 4796.31 & 26,656 & $11,820.00$ & 88 & 1.41 & 13 & 2.83 \\
\hline & & Tower juice 2 & $20,088.00$ & $12,682.67$ & 17,257 & 415.78 & 116.5 & 4.95 & 14 & 1.41 \\
\hline & & Cossette-juice mixture 1 & $25,381.50$ & 6385.88 & 14,483 & 2616.30 & 99 & 7.07 & 17 & 2.83 \\
\hline & & Cossette-juice mixture 2 & $19,220.50$ & $12,271.84$ & 28,385 & $11,631.91$ & 114 & 4.24 & 18.5 & 2.12 \\
\hline & & Raw juice & $79,043.50$ & $47,853.45$ & 24,697 & 7937.98 & 94.5 & 17.68 & 98 & 16.97 \\
\hline & \multirow{4}{*}{$\begin{array}{c}\text { Juice } \\
\text { purification }\end{array}$} & Hard juice & $181,206.50$ & $16,917.53$ & 198,801 & $30,549.84$ & 27.5 & 9.19 & 21.5 & 3.54 \\
\hline & & Thin juice & $91,786.00$ & $20,605.09$ & 109,973 & 5115.21 & 1 & 0.00 & 1 & 0.00 \\
\hline & & Eluat before UV & $10,240.00$ & 1012.58 & $17,774.5$ & 9613.12 & 4 & 0.00 & 10.5 & 9.19 \\
\hline & & Eluat after UV & $27,725.00$ & * & $11,998.5$ & 4780.75 & 4 & $*$ & 4 & 0.00 \\
\hline
\end{tabular}

* Only one Illumina MiSeq Sequencing analyze was possible.

The different conditions in the production process of beet sugar strongly influence the bacterial community. In the extraction area, bacteria belonging to the phylum Firmicutes were mainly detected. In juice purification, bacteria belonging to the phylum DeinococcusThermus were predominant. In the regenerate/eluat, which is used as fresh water in the extraction tower, bacteria belonging to the phyla Proteobacteria and Actinobacteria were primarily observed (Table 2). 


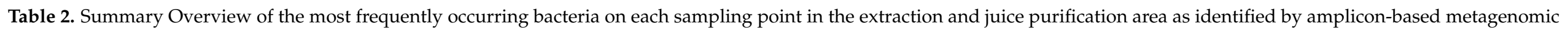

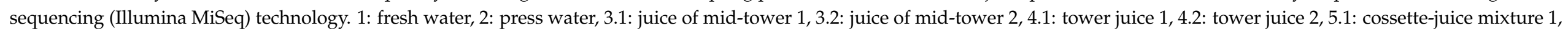
5.2: cossette-juice mixture 2, 6: raw juice, 7: hard juice, 8: thin juice, 9: regenerate before UV-treatment, 10: regenerate after UV-treatment.

\begin{tabular}{|c|c|c|c|c|c|c|c|c|c|c|}
\hline Genus & Family & Order & Class & Phylum & $\begin{array}{l}\text { Gram } \\
\text { Stain }\end{array}$ & Growth Temperature & $\begin{array}{l}\text { Relation to } \\
\text { Oxygen }\end{array}$ & $\begin{array}{c}\text { Spore } \\
\text { Former }\end{array}$ & Sample Point & Literature \\
\hline Tumebacillus & Alicyclobacillaceae & Bacillales & Bacilli & Firmicutes & positive & $5-37^{\circ} \mathrm{C}$ & aerobic & + & 2 & [33] \\
\hline Bacillus & Bacillaceae & Bacillales & Bacilli & Firmicutes & positive & $35-50{ }^{\circ} \mathrm{C}$ & $\begin{array}{l}\text { aerobic or mi- } \\
\text { croaerophilic }\end{array}$ & + & 2 & [34] \\
\hline Bacillus & Bacillaceae & Bacillales & Bacilli & Firmicutes & positive & $25-65{ }^{\circ} \mathrm{C}$ & $\begin{array}{c}\text { facultatively } \\
\text { anaerobic }\end{array}$ & + & 2 & [35] \\
\hline Geobacillus & Bacillaceae & Bacillales & Bacilli & Firmicutes & positive & $42-70{ }^{\circ} \mathrm{C}$ & anaerobic & + & $5.1 ; 5.2 ; 4.1 ; 4.2$ & {$[34,36]$} \\
\hline Geobacillus & Bacillaceae & Bacillales & Bacilli & Firmicutes & positive & $45-70{ }^{\circ} \mathrm{C}$ & aerobic & + & $5.1 ; 5.2 ; 4.1 ; 4.2$ & {$[34,37,38]$} \\
\hline Caenibacillus & $\begin{array}{l}\text { Sporolacto- } \\
\text { bacillaceae }\end{array}$ & Bacillales & Bacilli & Firmicutes & positive & $40-65{ }^{\circ} \mathrm{C}$ & aerobic & + & $3.1 ; 3.2 ; 4.1 ; 4.2$ & [40] \\
\hline Leuconostoc & Leuconostocaceae & Lactobacillales & Bacilli & Firmicutes & positive & $20-30{ }^{\circ} \mathrm{C}$ & anaerobic & - & 6 & [41] \\
\hline Leuconostoc & Leuconostocaceae & Lactobacillales & Bacilli & Firmicutes & positive & $20-30{ }^{\circ} \mathrm{C}$ & anaerobic & - & 6 & [41] \\
\hline Leuconostoc & Leuconostocaceae & Lactobacillales & Bacilli & Firmicutes & positive & $20-30{ }^{\circ} \mathrm{C}$ & anaerobic & - & 6 & [41] \\
\hline Leuconostoc & Leuconostocaceae & Lactobacillales & Bacilli & Firmicutes & positive & $20-30{ }^{\circ} \mathrm{C}$ & anaerobic & - & 6 & [41] \\
\hline Fructobacillus & Leuconostocaceae & Lactobacillales & Bacilli & Firmicutes & positive & $20-30{ }^{\circ} \mathrm{C}$ & aerobic & - & 6 & [42] \\
\hline Lactobacillus & Lactobacillaceae & Lactobacillales & Bacilli & Firmicutes & positive & at $45^{\circ} \mathrm{C}$, not at $15^{\circ} \mathrm{C}$ & anaerobic & - & 3.1 & [43] \\
\hline Lactobacillus & Lactobacillaceae & Lactobacillales & Bacilli & Firmicutes & positive & at $45^{\circ} \mathrm{C}$, not at $15^{\circ} \mathrm{C}$ & $\begin{array}{c}\text { micro } \\
\text { aerophilic }\end{array}$ & - & $2,3.1$ & [43] \\
\hline Lactobacillus & Lactobacillaceae & Lactobacillales & Bacilli & Firmicutes & positive & at $45^{\circ} \mathrm{C}$, not at $15^{\circ} \mathrm{C}$ & anaerobic & - & $2 ; 6$ & [43] \\
\hline Lactobacillus & Lactobacillaceae & Lactobacillales & Bacilli & Firmicutes & positive & at $45^{\circ} \mathrm{C}$, not at $15^{\circ} \mathrm{C}$ & anaerobic & - & 2 & [43] \\
\hline Lactobacillus & Lactobacillaceae & Lactobacillales & Bacilli & Firmicutes & positive & at $37^{\circ} \mathrm{C}$ & anaerobic & - & 6 & {$[44]$} \\
\hline Arthrobacter & Micrococcaceae & Actinomycetales & Actino-bacteria & Actinobacteria & positive & $30^{\circ} \mathrm{C}$ & aerobic & - & $1 ; 9 ; 10$ & {$[45,46]$} \\
\hline Ralstonia & Burkholderiaceae & Burkholderiales & $\begin{array}{l}\text { Betaproteo- } \\
\text { bacteria }\end{array}$ & Proteobacteria & negative & 28,30 and $37^{\circ} \mathrm{C}$ & aerobic & - & $1 ; 9 ; 10$ & [47] \\
\hline Burkholderia & Burkholderiaceae & Burkholderiales & $\begin{array}{l}\text { Betaproteo- } \\
\text { bacteria }\end{array}$ & Proteobacteria & negative & $30^{\circ} \mathrm{C}$ not at $42^{\circ} \mathrm{C}$ & aerobic & - & $1 ; 7 ; 9 ; 10$ & {$[48,49]$} \\
\hline Thermus & Thermaceae & Thermales & Deinococci & $\begin{array}{l}\text { Deinococcus- } \\
\text { Thermus }\end{array}$ & negative & $49-72{ }^{\circ} \mathrm{C}$ & $\begin{array}{l}\text { facultatively } \\
\text { anaerobic }\end{array}$ & - & $7 ; 8$ & [50-52] \\
\hline
\end{tabular}


Raw juice represents the sample with rather low temperature in the extraction area owing to the countercurrent processing principle resulting in highest alpha diversity (Table 3 , Figure S1 and Table S1). The fresh cossettes cool the juice coming from the extraction tower through the countercurrent mixer (Figure 1). This step results in a raw juice temperature of approximately $30^{\circ} \mathrm{C}$. The lower temperature causes the predominance of mesophilic bacteria, such as Leuconostoc and Lactobacillus species (Table 2). This finding supports the results of previous studies based on cultural methods $[8,12,13]$. In addition to the predominating phylum Firmicutes mentioned above, bacteria belonging to the phyla Proteobacteria, Actinobacteria, Acidobacteria, and Nitrospiraceae occur in raw juice. The microbiota of Chinese sugar beets in different growth stages of the plant was identified based on amplicon-based sequencing (Illumina technique) and resulted in bacterial groups of the same phyla as detected in this study [53]. These bacteria may have been washed off from fresh beet cossettes by the raw juice due to the countercurrent processing principle. In the previous process step, the extraction as well as in the following step, the juice purification, these bacteria could no longer be detected or were only measured at very low relative abundance. In the extraction area, countercurrent mixer and extraction tower (sample 3-5 in Table 2), a mixture of aerobic and anaerobic thermophilic endospore-forming bacteria could be found (Table 2). To extract sucrose from the cossettes, extraction water is used. This water consists of regenerated water from the regeneration of ion exchangers used to remove calcium from juice after the juice purification process, known as fresh water, and press water generated by pressing the exhausted cossettes (Figure 1). Bacteria detected in extraction water were rarely found or could not be detected in further steps in the extraction area. This absence of bacteria is observed because the fresh water in the investigated factory is treated with UV radiation. Press water showed high microbial contamination levels [13] and high alpha diversity (Table 3, Figure S1 and Table S1), but these bacteria were not predominant in the juice from the mid-tower or the tower juice. In both extraction lines, the bacterial community was very similar, except for the sampling point at the central part of the extraction tower. In the juice from mid-tower 1, Lactobacillus species were found (Table 2). This finding confirmed the results of a previous study based on culture methods, where a significantly higher number of lactic acid bacteria were detected in these samples from mid-tower 1 [13].

In the samples originating from juice purification, hard juice and thin juice, the calculated alpha diversity was very low (Table 3, Figure S1 and Table S1), and the Thermus species was found to be typical. Additionally, in hard juice, other bacterial species, such as Burkholderia species, could be detected, but this genus was no longer present in thin juice (Table 2). This finding may be attributable to bacteria that remained in the ion exchanger resin usually used for decalcification of the juice and were washed out in the regeneration cycle with the regenerate. Regarding the effect of high temperatures (approximately $80^{\circ} \mathrm{C}$ ) on the bacterial community and typical for the resin columns, it could be assumed that the Burkholderia cells are not viable. In previous studies, no aerobic mesophilic bacteria were detected in such samples. Nevertheless, microbial contamination of the resin has been reported in plant protocols. The regeneration treatment, which also mechanically affects the resin material, can cause cracks and crevices in the resin, where microorganisms can grow and persist. In this context, a previous study reported the occurrence of nitrite-forming Thermus species located in ion exchanger columns [51]. These species could not be identified in the regenerate, suggesting that they survive in the resin. No published investigation based on cultural methods could detect growth in hard and thin juice samples [54]. 


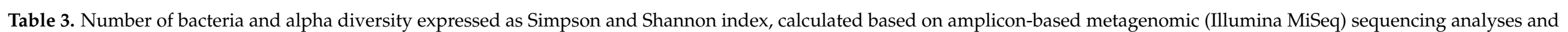

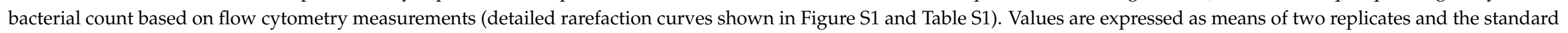
deviations (SD).

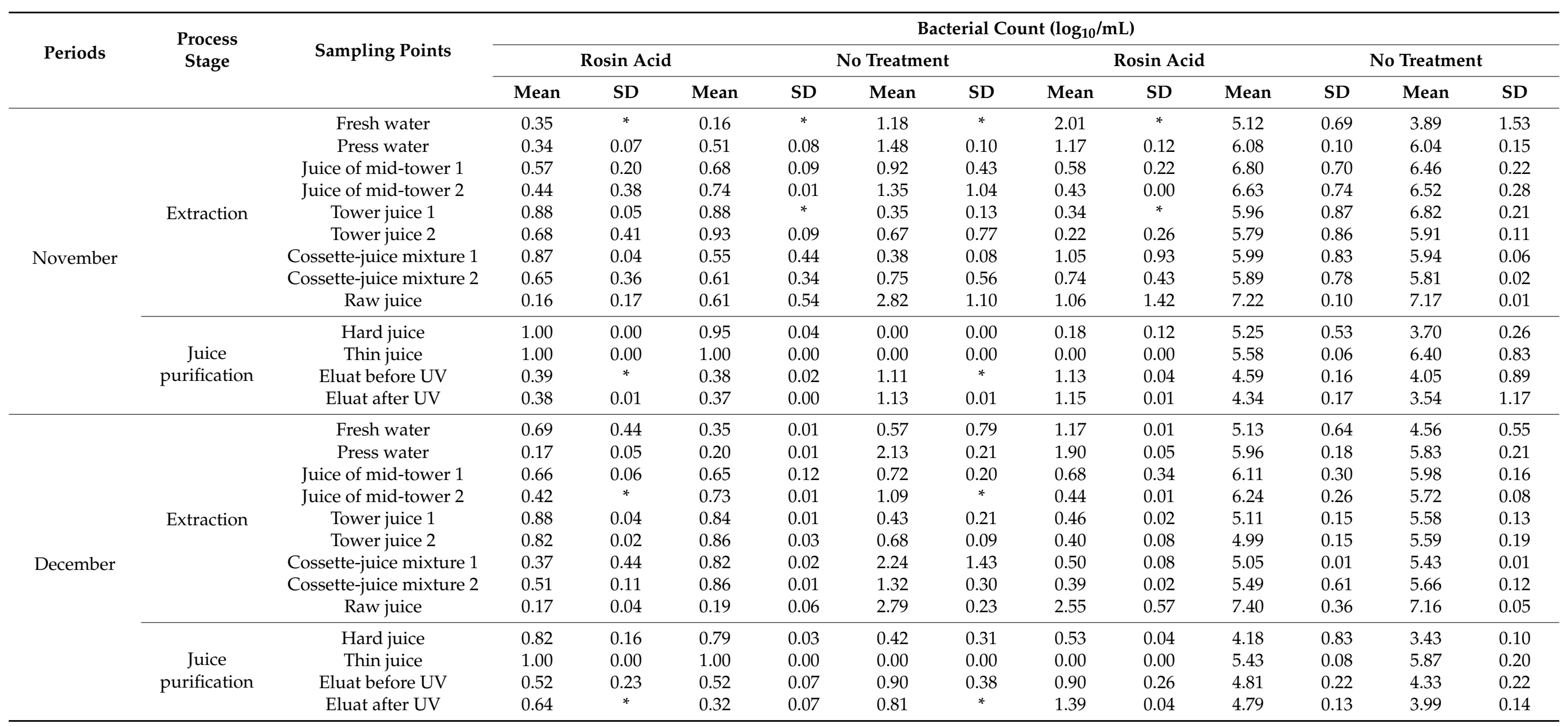


Table 3. Cont.

\begin{tabular}{|c|c|c|c|c|c|c|c|c|c|c|c|c|c|c|}
\hline \multirow{3}{*}{ Periods } & \multirow{3}{*}{$\begin{array}{l}\text { Process } \\
\text { Stage }\end{array}$} & \multirow{3}{*}{ Sampling Points } & \multicolumn{12}{|c|}{ Bacterial Count $\left(\log _{10} / \mathrm{mL}\right)$} \\
\hline & & & \multicolumn{3}{|c|}{ Rosin Acid } & \multicolumn{3}{|c|}{ No Treatment } & \multicolumn{3}{|c|}{ Rosin Acid } & \multicolumn{3}{|c|}{ No Treatment } \\
\hline & & & Mean & SD & Mean & SD & Mean & SD & Mean & SD & Mean & SD & Mean & SD \\
\hline \multirow{11}{*}{ January } & \multirow{7}{*}{ Extraction } & Press water & 0.18 & 0.06 & 0.28 & 0.03 & 2.06 & 0.21 & 1.59 & 0.08 & 6.11 & 0.06 & 6.14 & 0.17 \\
\hline & & Juice of mid-tower 1 & 0.48 & 0.22 & 0.55 & 0.12 & 1.08 & 0.39 & 0.99 & 0.32 & 5.95 & 0.07 & 4.69 & 2.64 \\
\hline & & Juice of mid-tower 2 & 0.12 & 0.05 & 0.73 & 0.00 & 2.58 & 0.31 & 0.48 & 0.02 & 5.64 & 0.01 & 6.31 & 0.21 \\
\hline & & Tower juice 1 & 0.65 & 0.11 & 0.68 & 0.32 & 1.32 & 0.36 & 0.63 & 0.46 & 5.27 & 0.11 & 5.31 & 0.33 \\
\hline & & Cossette-juice mixture 1 & 0.50 & 0.14 & 0.86 & 0.07 & 1.49 & 0.05 & 0.42 & 0.17 & 5.33 & 0.04 & 5.47 & 0.01 \\
\hline & & Cossette-juice mixture 2 & 0.25 & 0.33 & 0.65 & 0.28 & 3.07 & 1.94 & 0.75 & 0.44 & 5.46 & 0.02 & 5.61 & 0.02 \\
\hline & & Raw juice & 0.29 & 0.01 & 0.22 & 0.04 & 1.87 & 0.06 & 2.37 & 0.49 & 7.11 & 0.13 & 7.33 & 0.07 \\
\hline & \multirow{4}{*}{$\begin{array}{c}\text { Juice } \\
\text { purification }\end{array}$} & Hard juice & 0.91 & 0.08 & 0.96 & 0.00 & 0.28 & 0.23 & 0.13 & 0.01 & 3.25 & 0.09 & 3.58 & 0.09 \\
\hline & & Thin juice & 1.00 & 0.00 & 1.00 & 0.00 & 0.00 & 0.00 & 0.00 & 0.00 & 5.60 & 0.26 & 5.29 & 0.57 \\
\hline & & Eluat before UV & 0.36 & 0.00 & 0.37 & 0.03 & 1.15 & 0.00 & 1.25 & 0.09 & 3.31 & 0.04 & 4.90 & 0.19 \\
\hline & & Eluat after UV & 0.37 & $*$ & 0.37 & 0.00 & 1.13 & $*$ & 1.13 & 0.01 & 2.62 & 0.52 & 4.58 & 0.01 \\
\hline
\end{tabular}


The influence of the processing time period and the related storage period of the beet was also investigated in this study. Practical experience has shown that beets stored for an extended period of time are more difficult to process than fresh beets. The texture of the beets changes [55] and the changes in chemical composition of the beets during storage can lead to slicing problems also involving reduced processing quality [56]. The increase in levels of non-sucrose substances, such as betaine, raffinose and invert sugar (glucose and fructose), results in poor beet quality and a stronger need for processing aids [56]. For example, dextran can be produced by Leuconostoc species. This effect especially occurs after freeze-thaw cycles during the storage period of beets [57]. To prevent technological problems, the addition of dextranase is recommended in such cases. Deteriorated processing quality observed at the end of the season could be of microbiological origin, but our investigations showed no significant influence of processing period/storage duration on the diversity of the bacterial community in the process. The sampling points where different processing conditions are observed seem to be the primary influence on the diversity of the detected antimicrobial effects of rosin acids.

\subsection{Industrial-Scale Application of a Rosin Acid-Based Product in the Extraction Area}

In the 1990s, AGRANA company voluntarily stopped using formaldehyde to combat microorganisms in the production process. As an alternative, hop acid- or rosin acid-based products were used instead [18,58]. Previous studies have demonstrated a significant reduction in microbial metabolites, such as lactic acid, acetic acid, butyric acid, glucose and fructose, due to the application of a rosin acid-based product in the extraction area, but no influence on microbial counts was detected [13]. These culture method-based results could be confirmed with a culture-independent method, flow cytometry. No significant difference in the total number of bacteria in the samples was detected in the samples with and without rosin acid application in the industrial or laboratory batch trials. The alpha diversity expressed as the Simpson and Shannon indices increased significantly $(p=0.0110$ and $p=0.0064$ ) when only samples from the extraction tower and countercurrent mixer were included in the statistical analyses, where the product was dosed. Furthermore, the dosing also influenced the increasing diversity at all sampling points, which also included samples from juice purification (Table 4).

Table 4. Statistical evaluation of significant differences of bacterial count, based on flow cytometric analyses, alpha diversity expressed as Simpson and Shannon index and OTU quantity, based on Illumina sequencing based on MiSeq analyses. Samples of extraction area and juice purification with or without treatment (adding of rosin acid-based product in extraction area) were statistically analyzed; calculations are based on repeated measures analysis and contrast analysis with Bonferroni correction at a significant level of $5 \%$.

\begin{tabular}{ccccccc}
\hline Responses & $\boldsymbol{N}$ & $\boldsymbol{n}$ & $\begin{array}{c}\text { Processing } \\
\text { Periods } \\
\left(p \text {-Values }{ }^{*}\right)\end{array}$ & $\begin{array}{c}\text { Contrast Analysis: } \\
\text { Significant Difference } \\
\text { between }\end{array}$ & $\begin{array}{c}\text { Treatments } \\
\left(p \text {-Values }{ }^{*}\right)\end{array}$ & $\begin{array}{c}\text { Sampling Points } \\
(p \text {-Values *) }\end{array}$ \\
\hline$\left(\log _{10}\right)$ Bacterial Count & 78 & 2 & 0.0101 & November and January & 0.7794 & $<0.0001$ \\
Simpson Index & 70 & 2 & 0.1506 & & 0.0559 & $<0.0001$ \\
Shannon Index & 70 & 2 & 0.1528 & & 0.0244 & 0.0006 \\
OTU Quantity & 70 & 2 & 0.0584 & November and January & 0.0007 & $<0.0001$ \\
\hline
\end{tabular}

$N$, complete cases; $n$, replicates of measurements; no significant interactions between the model effects with the exception of treatmentsampling points at OTU. * Effects were considered as significant at $p<0.05$.

In some samples, only the relative abundance of the microorganism shifted, but in others, additional bacterial species were detected. In tower juice and in the cossette-juice mixture, the alpha diversity also increased due to the occurrence of additional bacteria belonging to Actinobacteria, such as Arthrobacter and Proteobacteria. These bacteria may have been detected because some of them were gram-negative. Rosin acid-based products are not effective against Gram-negative bacteria [59]. Thus, the dosing of the rosin acid-based product caused a shift in the bacterial community composition. 


\subsection{Lab Scale Trials Using a Rosin Acid-Based Product}

Treatment with the rosin acid-based product had no significant influence on the total number of bacteria in the mini-fermenter trials. However, the total number of bacteria decreased significantly during the trial period $(p<0.05)$. By dosing the rosin acid-based product, the L-lactic acid concentration was reduced significantly $(p<0.05)$ compared to no dosing. Furthermore, the number of living cells decreased significantly immediately after dosing the rosin acid product $(p=0.0220)$. The L-lactic acid concentration over the trial period was also significantly lower $(p<0.05)$ in samples from the fermenter treated with rosin acid-based product compared to untreated samples at the same stage of trial. The treatment showed no significant effect on total count of viable cells over the trial period compared with untreated samples at the same stage of the trial. These observations indicate on the one hand a very specific effect of rosin acids on certain bacterial species. While the concentration is bactericidal for some species, for others, it is only inhibiting (bacteriostatic) for a certain time period. Emerstorfer et al. described the bactericidal concentration for different gram-positive bacteria. Rosin acids (10-15 mg/kg) inhibited the growth of different Clostridia species. For Lactobacilli, the concentration was considerably higher (up to $400 \mathrm{mg} / \mathrm{kg}$ ) [59]. On the other hand, if only total living cells were considered, it could be misleadingly assumed that the dosing of rosin acid-based product is not necessary to combat microorganisms in the extraction process. Our study showed that the viable cells undergoing no treatment were more active and secreted L-lactic acid by sucrose assimilation during the trial, while the $\mathrm{pH}$ value was constant for $6.0 \pm 2.60 \mathrm{~h}$ (values not shown) when treated with $3.0 \mathrm{mg} / \mathrm{L}$ of the rosin acid-based product. This bacteriostatic effect was confirmed by data from large-scale studies in the Austrian beet sugar plant. The low $\mathrm{pH}$ value caused by lactic acid production is responsible for additional sucrose losses by hydrolytic cleavage. A typical rate is $14-44 \mathrm{mg}$ per $100 \mathrm{~g}$ sucrose at $60^{\circ} \mathrm{C}-70{ }^{\circ} \mathrm{C}$ and a $\mathrm{pH}$ of 5.4 [60]. At the end of the trial, the number of viable cells was higher in the samples of the rosin-acid-treated mini-fermenter compared to the control (see Figures 2 and 3).

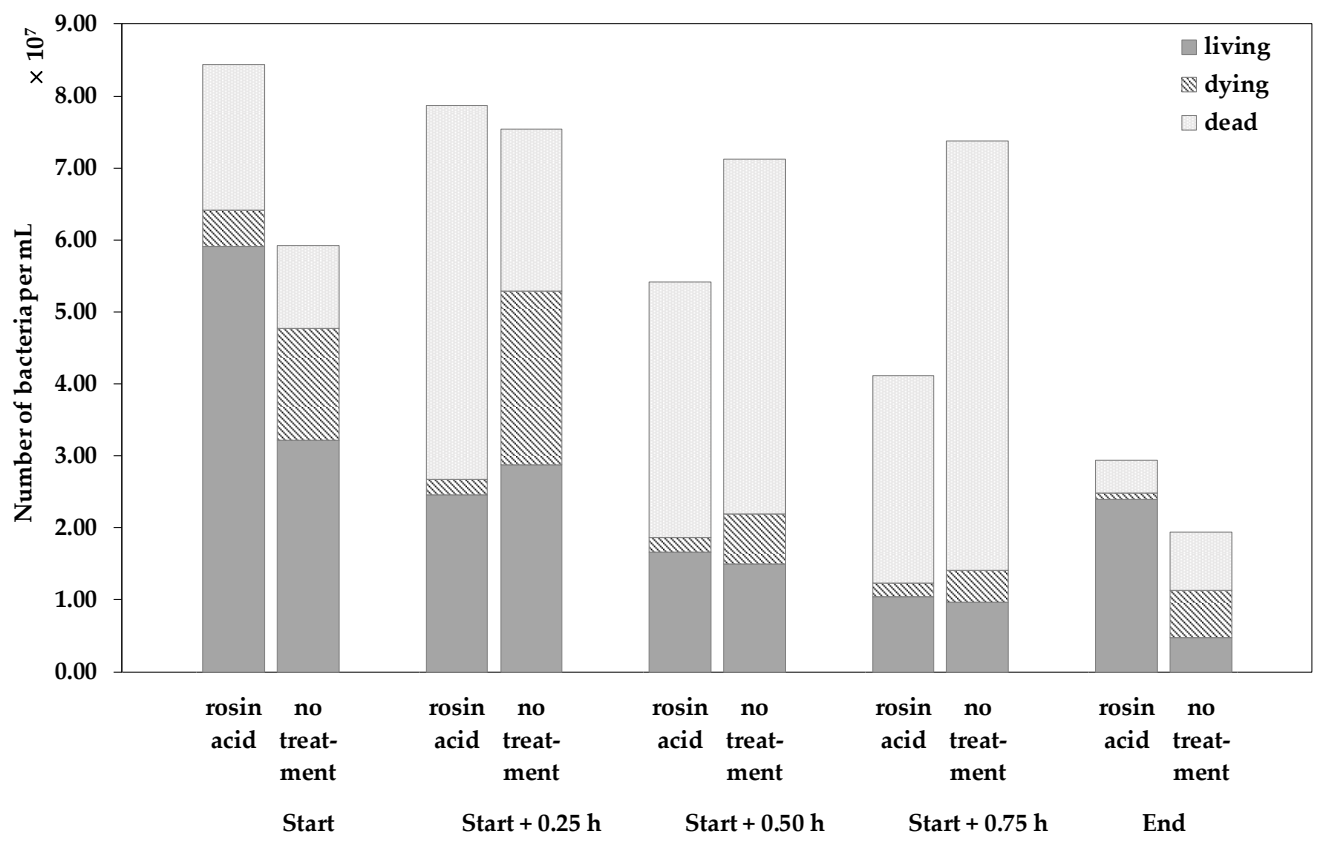

Figure 2. Bacterial count of living, dying and dead bacteria determined by means of flow cytometry investigating samples drawn from a mini-fermenter (calculated as an average of three independent trials) after different time points after treating with rosin acids $(3 \mathrm{mg} / \mathrm{L})$ or without treatment and after $24 \mathrm{~h}$ (end of trial period). 
(a)

(b)
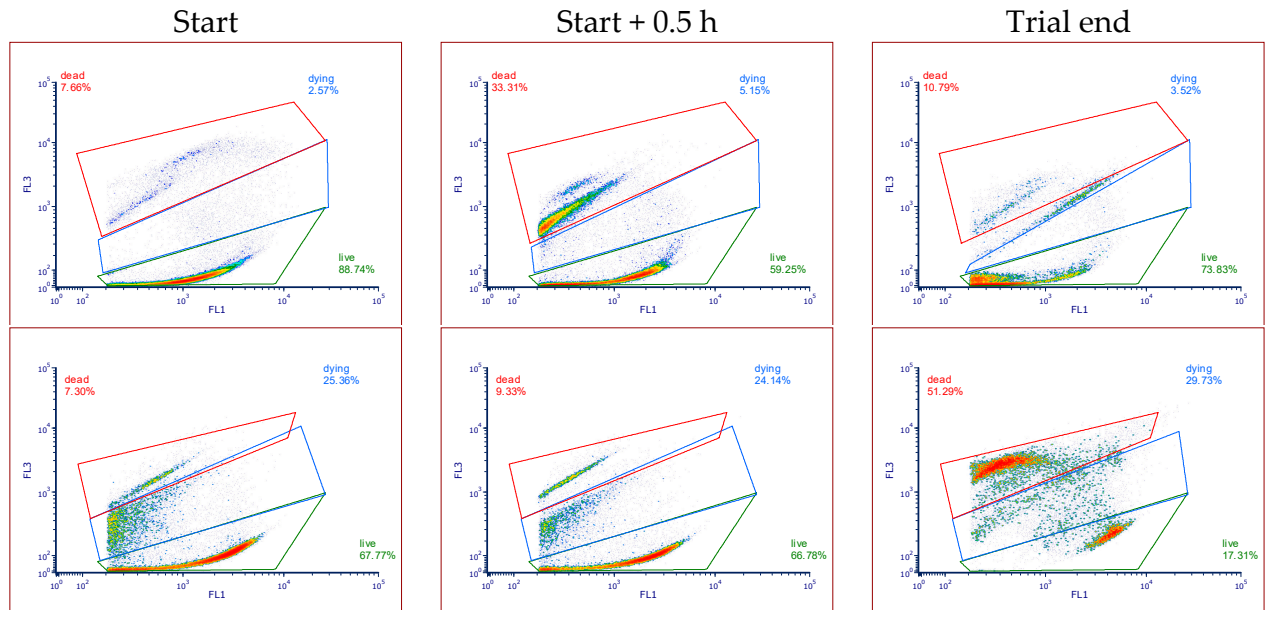

Figure 3. Representative flow cytometer scatter plots of living, dying and dead bacterial cells stained with SYBR Green (FL1) and Propidium Iodide (FL3) (a) sampled from mini-fermenters treated with $3 \mathrm{mg} / \mathrm{L}$ rosin acid-based product (Defostab 220) compared to $(\mathbf{b})$ mini-fermenters without treatment at different time points (Start: $\mathrm{pH}<5.8$, Start $+0.5 \mathrm{~h}$ and at the end of the trial period of $24 \mathrm{~h}$ ).

Additionally, the metabolic activity of the bacteria, such as the formation of organic acids, increased (Table 5). This result indicates that these bacteria had or developed tolerance and adapted to rosin acids or that rosin acids were no longer active due to absorption into the matrix or similar processes. To prohibit bacterial growth, further dosing may be necessary, which is the case in the sampled beet sugar extraction plant.

Table 5. L-Lactic acid concentration and $\mathrm{pH}$-value of samples treated with $(3 \mathrm{mg} / \mathrm{L})$ or without a rosin acid-based product and as monitored in mini-fermenter trials; values are expressed as mean and standard deviation of three independent trials. Start: $\mathrm{pH}<5.8$, start of treatment; End: End of trial, $24 \mathrm{~h}$.

\begin{tabular}{ccccccc}
\hline \multirow{2}{*}{ Treatment } & $\begin{array}{c}\text { Analyzed } \\
\text { Parameter }\end{array}$ & Start & Start $+\mathbf{0 . 2 5} \mathbf{h}$ & Start $+\mathbf{0 . 5} \mathbf{h}$ & Start + 0.75 h & End \\
& L-Lactic acid (mg/L) & $586 \pm 83$ & $655 \pm 73$ & $676 \pm 50$ & $676 \pm 47$ & $956 \pm 265$ \\
\cline { 2 - 7 } Rosin acids & $\mathrm{pH}$ & $5.78 \pm 0.01$ & $5.66 \pm 0.03$ & $5.65 \pm 0.04$ & $5.65 \pm 0.04$ & $5.31 \pm 0.21$ \\
\hline \multirow{2}{*}{ No treatment } & L-Lactic acid (mg/L) & $681 \pm 41$ & $838 \pm 108$ & $966 \pm 217$ & $979 \pm 222$ & $1410 \pm 219$ \\
\cline { 2 - 8 } & $\mathrm{pH}$ & $5.78 \pm 0.01$ & $5.56 \pm 0.19$ & $5.45 \pm 0.27$ & $5.42 \pm 0.28$ & $4.99 \pm 0.16$ \\
\hline
\end{tabular}

\section{Conclusions}

Compared to $16 \mathrm{~S}$ amplicon-based metagenome analysis, the classical characterization of typical microorganisms associated with beet sugar plants are often based on cultural methods, as it only provides an incomplete picture of the real bacterial community. This observation is especially true for the samples from the high-temperature part of the extraction area, the juice of the central part of the tower, the tower juice and the cossette-juice mixture. The set of cultural-based methods has to be extended by specific media and culturing conditions for species such as Geobacillus spp. and Caenibacillus spp. Based on lab-scale experiments accompanied by industrial-scale administration of rosin acids, specific antimicrobial effects and their persistence could be clarified in this study. As a result of addition of the antimicrobial, the total number of bacteria and the production of metabolites such as L-lactic acid could be reduced. However, the rosin acids-based product was only effective for a certain time period. Then, microbial growth including the production of metabolites started again. Further studies will be necessary to investigate more in depth the effect of rosin acids on the cellular level of the bacteria, as well as its stability under processing conditions. 
Supplementary Materials: The following are available online at https://www.mdpi.com/2076-3 417/11/2/737/s1, Figure S1: Rarefaction curves of alpha diversity (Simpson and Shannon) of all samples of the industrial trail in 2017/2018 in an Austrian sugar beet factory using $3 \mathrm{mg} / \mathrm{L}$ rosin acid-based product (Defostab 220) compared with no treatment. Detailed sample description in Supplementary Table S1, Table S1: Data description of Supplementary Figure S1 including sampling code, sampling point, sampling date and treatment with $3 \mathrm{mg} / \mathrm{L}$ rosin acid-based product (Defostab 220) during the sugar beet process. 0: no treatment.

Author Contributions: Conceptualization, C.K.M., F.E. and K.J.D.; data curation, C.K.M. and C.U.; funding acquisition, F.E.; investigation, C.K.M. and C.U.; methodology, C.K.M., C.U. and U.Z.; project administration, C.K.M. and F.E.; resources, F.E. and K.J.D.; software, C.K.M. and U.Z.; supervision, W.K. and K.J.D.; validation, C.K.M. and U.Z.; visualization, C.K.M.; writing-original draft, C.K.M.; writing-review \& editing, C.U., U.Z., F.E., W.H., W.K. and K.J.D. All authors have read and agreed to the published version of the manuscript.

Funding: This project was funded by the Austrian Research Promotion Agency (Österreichische Forschungsförderungsgesellschaft: FFG) with the grant number 857111.

Data Availability Statement: The data presented in this study are available in this article and supplementary materials.

Acknowledgments: The library construction, sequencing and data analysis described in Section 2.3 were performed by Microsynth AG (Balgach, Switzerland). Technological support for the industrial trial by sugar beet factory Tulln. Technical support for flow cytometer by M. Grilz, company Sysmex. My thanks also go to the colleagues in the factory who carried out the industrial scale application of rosin acid-based product.

Conflicts of Interest: The funders had no role in the design of the study; in the collection, analyses, or interpretation of data; in the writing of the manuscript, or in the decision to publish the results.

\section{References}

1. Van der Poel, P.W. Zuckertechnologie. Rüben- und Rohrzuckergewinnung; Dr. Albert Bartens KG: Berlin, Germany, 2000.

2. Klaushofer, H.; Clarke, M.A.; Rein, P.W.; Mauch, W. Mikrobiologie. In Zuckertechnologie. Rüben- und Rohrzuckergewinnung; Van der Poel, P.W., Schiweck, H., Schwartz, T., Eds.; Dr. Albert Bartens KG: Berlin, Germany, 2000.

3. Krüger, W. Über Infektion und Zuckerverlust im Diffusionsturm. In Proceedings of the Commission Internationale Technique de Sucrerie, Frankfurt, Germany, 26 October 1957; pp. 191-195.

4. Bidan, P.; Blanchet, M.; Genotelle, J. Evaluation expérimentale des pertes de sucre d'origine microbienne en diffusion. Industr. Alim. Agr. 1963, 80, 717-720.

5. Hollaus, F. Eine einfache Methode zur quantitativen Bestimmung mikrobieller Stoffumsetzungen mittels Objektträgerkulturen. Ernährung/Nutrition 1978, 2, 196-198.

6. Klaushofer, H.; Hollaus, F. Zur Taxonomie der hochthermophilen, in Zuckerfabriksäften vorkommenden aeroben Sporenbildner. Sugar Ind. 1970, 20, 465-470.

7. Belamri, M.; Mekkaoui, A.K.; Tantaoui-Elaraki, A. Saccharolytic bacteria in beet juices. Int. Sugar J. 1991, 93, $210-212$.

8. Robles-Gancedo, S.; Lopez-Diaz, T.M.; Otero, A. Microbiological counts during beet sugar extraction. J. Food Prot. 2009, 72, 1332-1337. [CrossRef]

9. Juste, A.; Thomma, B.P.; Lievens, B. Recent advances in molecular techniques to study microbial communities in food-associated matrices and processes. Food Microbiol. 2008, 25, 745-761. [CrossRef]

10. Franco-Duarte, R.; Černáková, L.; Kadam, S.; Kaushik, K.S.; Salehi, B.; Bevilacqua, A.; Corbo, M.R.; Antolak, H.; Dybka-Stępień, K.; Leszczewicz, M.; et al. Advances in Chemical and Biological Methods to Identify Microorganisms-From Past to Present. Microorganisms 2019, 7, 130. [CrossRef]

11. Justé, A.; Krause, M.S.; Lievens, B.; Klingeberg, M.; Michiels, C.W.; Willems, K.A. Protective effect of hop $\beta$-acids on microbial degradation of thick juice during storage. J. Appl. Microbiol. 2008, 104, 51-59. [CrossRef]

12. Robles-Gancedo, S.; López-Díaz, T.M.; Otero, A. Identification of main bacteria and fungi found during beet sugar extraction in Spanish factories. Int. Sugar J. 2014, 116, 29.

13. Kohout, C.K.; Ukowitz, C.; Reiter, D.; Zitz, U.; Moder, K.; Emerstorfer, F.; Hein, W.; Kneifel, W.; Domig, K.J. Bacterial growth dynamics and corresponding metabolite levels in the extraction area of an Austrian sugar beet factory using antimicrobial treatment. J. Sci. Food Agric. 2020, 100, 2713-2721. [CrossRef]

14. Díaz, M.; Herrero, M.; García, L.A.; Quirós, C. Application of flow cytometry to industrial microbial bioprocesses. Biochem. Eng. J. 2010, 48, 385-407. [CrossRef]

15. Longin, C.; Petitgonnet, C.; Guilloux-Benatier, M.; Rousseaux, S.; Alexandre, H. Application of flow cytometry to wine microorganisms. Food Microbiol. 2017, 62, 221-231. [CrossRef] [PubMed] 
16. Muñoz, M.; Guevara, L.; Palop, A.; Tabera, J.; Fernández, P.S. Determination of the effect of plant essential oils obtained by supercritical fluid extraction on the growth and viability of Listeria monocytogenes in broth and food systems using flow cytometry. LWT 2009, 42, 220-227. [CrossRef]

17. Pollach, G.; Hein, W.; Beddie, D. Application of hop- $\beta$-acids and rosin acids in the sugar industry. Sugar Ind. 2002, 127, 921-930.

18. Hein, W.; Pollach, G.; Emerstorfer, F. 10 years' experience with natural antibacterials within Agrana. Sugar Ind. 2006, 131, 477-491.

19. Andrews, S. Fast QC. Available online: http:/ / www.bioinformatics.babraham.ac.uk/projects/fastqc/ (accessed on 28 June 2019 ).

20. Martin, M. Cutadapt removes adapter sequences from high-throughput sequencing reads. EMBnet J. 2011, 17, 3. [CrossRef]

21. Edgar, R.C. Search and clustering orders of magnitude faster than BLAST. Bioinformatics 2010, 26, 2460-2461. [CrossRef]

22. Edgar, R.C. UNOISE2: Improved error-correction for Illumina $16 \mathrm{~S}$ and ITS amplicon sequencing. BioRxiv 2016, 081257. [CrossRef]

23. Edgar, R.C. UNBIAS: An attempt to correct abundance bias in $16 S$ sequencing, with limited success. BioRxiv 2017, 124149. [CrossRef]

24. Edgar, R.C. UNCROSS2: Identification of cross-talk in 16S rRNA OTU tables. BioRxiv 2018, 400762. [CrossRef]

25. Edgar, R.C. SINTAX: A simple non-Bayesian taxonomy classifier for 16S and ITS sequences. BioRxiv 2016, 074161. [CrossRef]

26. Cole, J.R.; Wang, Q.; Fish, J.A.; Chai, B.; McGarrell, D.M.; Sun, Y.; Brown, C.T.; Porras-Alfaro, A.; Kuske, C.R.; Tiedje, J.M. Ribosomal Database Project: Data and tools for high throughput rRNA analysis. Nucleic Acids Res. Spec. Publ. 2013, 42, D633-D642. [CrossRef] [PubMed]

27. Ondov, B.D.; Bergman, N.H.; Phillippy, A.M. Interactive metagenomic visualization in a Web browser. BMC Bioinf. 2011, $12,385$. [CrossRef] [PubMed]

28. Wang, Y.; Sheng, H.F.; He, Y.; Wu, J.Y.; Jiang, Y.X.; Tam, N.F.; Zhou, H.W. Comparison of the levels of bacterial diversity in freshwater, intertidal wetland, and marine sediments by using millions of illumina tags. Appl. Environ. Microbiol. 2012, 78, 8264-8271. [CrossRef] [PubMed]

29. He, F.; Hu, X.-S. Hubbell's fundamental biodiversity parameter and the Simpson diversity index. Ecol. Lett. 2005, 8, 386-390. [CrossRef]

30. Qiu, Z.; Li, N.; Lu, X.; Zheng, Z.; Zhang, M.; Qiao, X. Characterization of microbial community structure and metabolic potential using Illumina MiSeq platform during the black garlic processing. Food Res. Int. 2018, 106, 428-438. [CrossRef] [PubMed]

31. Bensch, G.; Rüger, M.; Wassermann, M.; Weinholz, S.; Reichl, U.; Cordes, C. Flow cytometric viability assessment of lactic acid bacteria starter cultures produced by fluidized bed drying. Appl. Microbiol. Biotechnol. 2014, 98, 4897-4909. [CrossRef]

32. Dr. Müller Gerätebau GmbH. Gebrauchsanweisung—Super GL Compact; Dr. Müller Gerätebau GmbH: Freital, Germany, 2011; Version 2.0; pp. 1-50.

33. Steven, B.; Chen, M.Q.; Greer, C.W.; Whyte, L.G.; Niederberger, T.D. Tumebacillus permanentifrigoris gen. nov., sp. nov., an aerobic, spore-forming bacterium isolated from Canadian high Arctic permafrost. Int. J. Syst. Evol. Microbiol. 2008, 58, 1497-1501. [CrossRef]

34. Abriouel, H.; Benomar, N.; Huch, M.; Franz, C.M.A.P.; Gálvez, A. The genera Bacillus, Geobacillus and Halobacillus. In Lactic Acid Bacteria: Biodiversity and Taxonomy; Holzapfel, W.H., Wood, B.J.B., Eds.; Wiley: Hoboken, NJ, USA, 2014.

35. Bosma, E.F.; Koehorst, J.J.; van Hijum, S.A.; Renckens, B.; Vriesendorp, B.; van de Weijer, A.H.; Schaap, P.J.; de Vos, W.M.; van der Oost, J.; van Kranenburg, R. Complete genome sequence of thermophilic Bacillus smithii type strain DSM 4216(T). Stand. Genom. Sci. 2016, 11, 52. [CrossRef]

36. Fortina, M.G.; Mora, D.; Schumann, P.; Parini, C.; Manachini, P.L.; Stackebrandt, E. Reclassification of Saccharococcus caldoxylosilyticus as Geobacillus caldoxylosilyticus (Ahmad et al. 2000) comb. nov. Int. J. Syst. Evol. Microbiol. 2001, 51, 2063-2071. [CrossRef]

37. Poli, A.; Romano, I.; Caliendo, G.; Nicolaus, G.; Orlando, P.; de Falco, A.; Lama, L.; Gambacorta, A.; Nicolaus, B. Geobacillus toebil subsp. decanicus subsp. nov., a hydrocarbon-degrading, heavy metal resistant bacterium from hot compost. J. Gen. Appl. Microbiol. 2006, 52, 223-234. [CrossRef] [PubMed]

38. Sung, M.-H.; Kim, H.; Bae, J.; Rhee, S.; Jeon, C.; Kim, K.; Kim, J.-J.; Hong, S.; Lee, S.-G.; Yoon, J.-W.; et al. Geobacillus toebii sp. nov., a novel thermophilic bacterium isolated from hay compost. Int. J. Syst. Evol. Microbiol. 2002, 52, 2251-2255. [CrossRef] [PubMed]

39. Poli, A.; Romano, I.; Cordella, P.; Orlando, P.; Nicolaus, B.; Ceschi Berrini, C. Anoxybacillus thermarum sp. nov., a novel thermophilic bacterium isolated from thermal mud in Euganean hot springs, Abano Terme, Italy. Extremophiles 2009, 13, 867-874. [CrossRef] [PubMed]

40. Tsujimoto, Y.; Saito, R.; Furuya, H.; Ishihara, D.; Sahara, T.; Kimura, N.; Nishino, T.; Tsuruoka, N.; Shigeri, Y.; Watanabe, K. Caenibacillus caldisaponilyticus gen. nov., sp. nov., a thermophilic, spore-forming and phospholipid-degrading bacterium isolated from acidulocompost. Int. J. Syst. Evol. Microbiol. 2016, 66, 2684-2690. [CrossRef] [PubMed]

41. Björkroth, J.; Dicks, L.M.T.; Endo, A.H. The genus Leuconostoc. In Lactic Acid Bacteria: Biodiversity and Taxonomy; Holzapfel, W.H., Wood, B.J.B., Eds.; Wiley: Hoboken, NJ, USA, 2014; pp. 391-404.

42. Endo, A.; Dicks, L.M.T. The genus Fructobacillus. In Lactic Acid Bacteria: Biodiversity and Taxonomy; Holzapfel, W.H., Wood, B.J.B., Eds.; Wiley: Hoboken, NJ, USA, 2014; pp. 381-390.

43. Pot, B.; Felis, G.E.; De Bruyne, K.; Tsakalidou, E.; Papadimitriou, K.; Leisner, J.; Vandamme, P. The genus Lactobacillus. In Lactic Acid Bacteria: Biodiversity and Taxonomy; Holzapfel, W.H., Wood, B.J.B., Eds.; Wiley: Hoboken, NJ, USA, $2014 ;$ pp. $249-354$.

44. Torriani, S.; Felis, G.E.; Dellaglio, F. Differentiation of Lactobacillus plantarum, L. pentosus, and L. paraplantarum by recA gene sequence analysis and multiplex PCR assay with recA gene-derived primers. Appl. Environ. Microbiol. 2001, 67, 3450-3454. [CrossRef] [PubMed]

45. Li, Y.; Kawamura, Y.; Fujiwara, N.; Naka, T.; Liu, H.; Huang, X.; Kobayashi, K.; Ezaki, T. Rothia aeria sp. nov., Rhodococcus baikonurensis sp. nov. and Arthrobacter russicus sp. nov., isolated from air in the Russian space laboratory Mir. Int. J. Syst. Evol. Microbiol. 2004, 54, 827-835. [CrossRef] 
46. Ding, L.; Hirose, T.; Yokota, A. Four novel Arthrobacter species isolated from filtration substrate. Int. J. Syst. Evol. Microbiol. 2009, 59, 856-862. [CrossRef]

47. Coenye, T.; Goris, J.; De Vos, P.; Vandamme, P.; LiPuma, J.J. Classification of Ralstonia pickettii-like isolates from the environment and clinical samples as Ralstonia insidiosa sp. nov. Int. J. Syst. Evol. Microbiol. 2003, 53, 1075-1080. [CrossRef]

48. Coenye, T.; Laevens, S.; Willems, A.; Ohlen, M.; Hannant, W.; Govan, J.R.; Gillis, M.; Falsen, E.; Vandamme, P. Burkholderia fungorum sp. nov. and Burkholderia caledonica sp. nov., two new species isolated from the environment, animals and human clinical samples. Int. J. Syst. Evol. Microbiol. 2001, 51, 1099-1107. [CrossRef]

49. Coenye, T.; Vandamme, P. Diversity and significance of Burkholderia species occupying diverse ecological niches. Environ. Microbiol. 2003, 5, 719-729. [CrossRef]

50. Alvarez, L.; Bricio, C.; Blesa, A.; Hidalgo, A.; Berenguer, J. Transferable denitrification capability of Thermus thermophilus. Appl. Environ. Microbiol. 2014, 80, 19-28. [CrossRef] [PubMed]

51. Hollaus, F.; Hein, W.; Pollach, G.; Scheberl, A.; Messner, P. Nitrit formation in the thin juice by Thermus species. Sugar Ind. 1997, 122, 365-369.

52. Beffa, T.; Blanc, M.; Lyon, P.; Vogt, G.; Marchiani, M.; Fischer, J.; Aragno, M. Isolation of Thermus Strains from Hot Composts (60 to $\left.80^{\circ} \mathrm{C}\right)$. Appl. Environ. Microbiol. 1996, 62, 1723-1727. [CrossRef]

53. Shi, Y.; Yang, H.; Zhang, T.; Sun, J.; Lou, K. Illumina-based analysis of endophytic bacterial diversity and space-time dynamics in sugar beet on the north slope of Tianshan mountain. Appl. Environ. Microbiol. 2014, 98, 6375-6385. [CrossRef] [PubMed]

54. Nemec, A. Leistungsspezifische Charakterisierung von Schwachsaurem Kationentauscherharz in Verschiedenen Medien. Bachelor's Thesis, Universität für Bodenkultur, Vienna, Austria, 2018.

55. Madritsch, S.; Bomers, S.; Posekany, A.; Gurg, A.; Birke, R.; Emerstorfer, F.; Turetschek, R.; Otte, S.; Eigner, H.; Sehr, E.M. Integrative transcriptomics reveals genotypic impact on sugar beet storability. Plant. Mol. Biol. 2020, 104, 359-378. [CrossRef] [PubMed]

56. Kenter, C.; Hoffmann, C.M. Changes in the processing quality of sugar beet (Beta vulgaris L.) during long-term storage under controlled conditions. Int. J. Food. Sci. Technol. 2009, 44, 910-917. [CrossRef]

57. Abraham, K.; Flöter, E. New approaches for the determination of dextran in the sugar production process. Sugar Ind. 2018, 143, 1-9. [CrossRef]

58. Pollach, G.; Hein, W. Method for Producing Sugar by Aid of Resins. Austria Patent 1,282,731B1, 19 April 2006.

59. Emerstorfer, F.; Kneifel, W.; Hein, W. The role of plant-based antimicrobials in food and feed production with special regard to silage fermentation. Bodenkultur 2009, 60, 55-65.

60. Bubnik, Z.; Kadlec, P.; Urban, D.; Bruhns, M. Sugar Technologists Manual; Dr. Albert Bartens KG: Berlin, Germany, $1995 ;$ Volume 8. 